\title{
Regional Structure of the
}

Southeast Missouri and

\section{Illinois-Kentucky}

Mineral Districts

GEOLOGICAL SURVEY BULLETIN 1202-B 


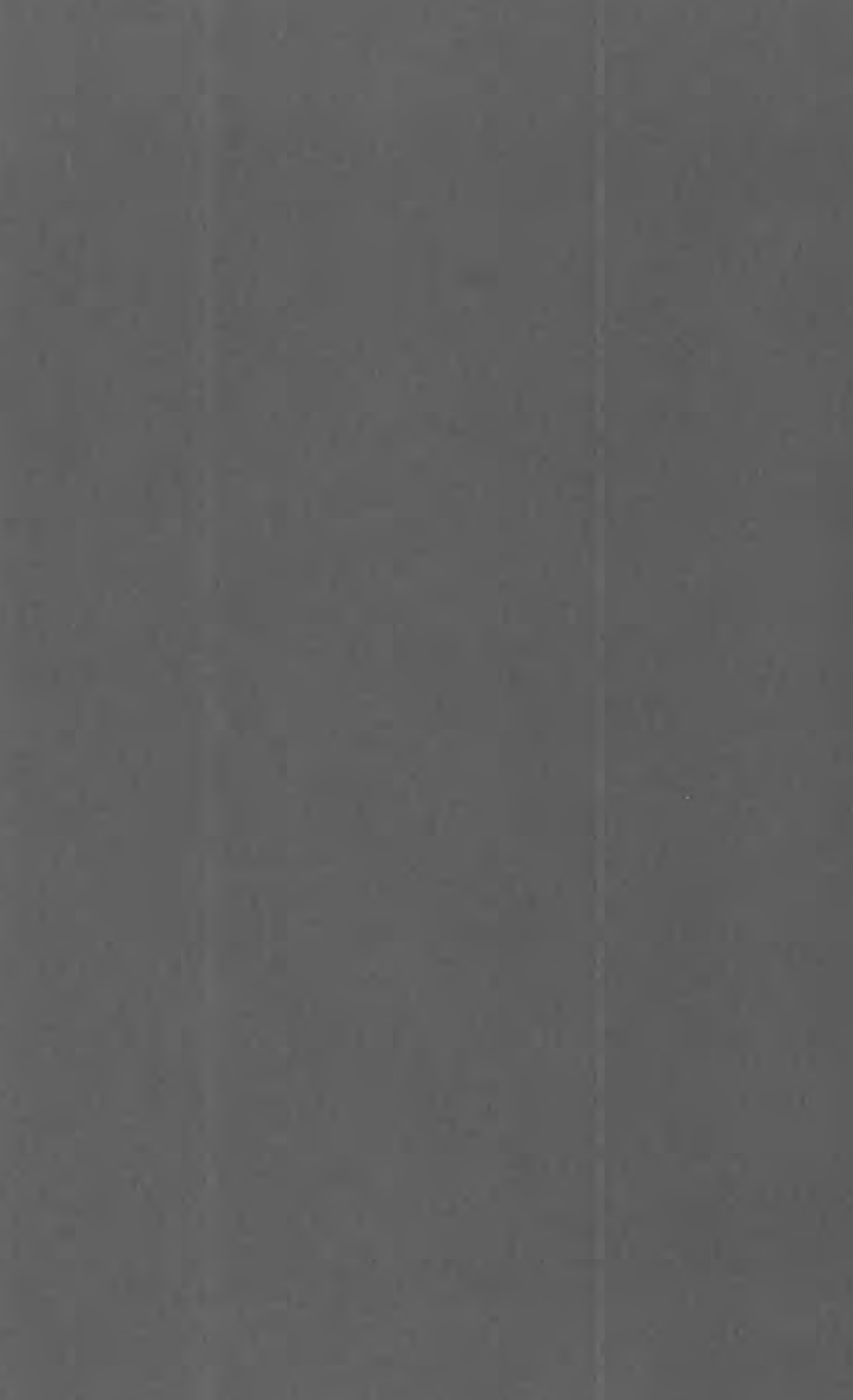




\section{Regional Structure of the}

Southeast Missouri and

\section{Illinois-Kentucky \\ Mineral Districts}

By A. V. HEYL, M. R. BROCK, J. L. JOLLY, and C. E. WELLS

CONTRIBUTIONS TO ECONOMIC GEOLOGY

GE OLOGICAL S U R VEY B ULLETIN $1202-\mathrm{B}$

A study of the principal geologic structures and mines in and between two major mineral-producing districts

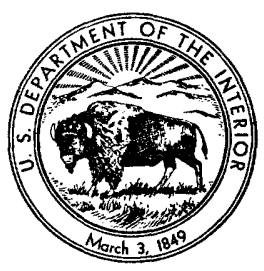


UNITED STATES DEPARTMENT OF THE INTERIOR

STEWART L. UDALL, Secretary

\author{
GEOLOGICAL SURVEY
}

Thomas B. Nolan, Director 


\section{CONTENTS}

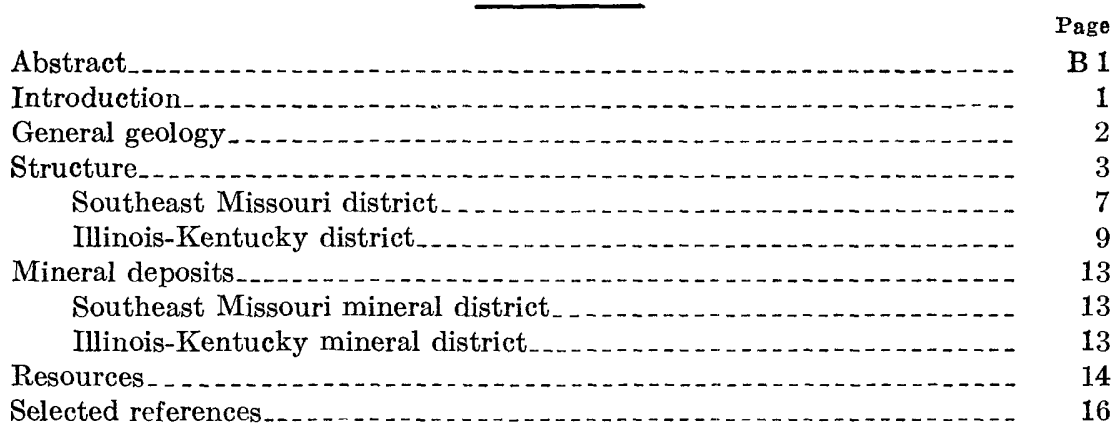

\section{ILLUSTRATIONS}

[Plates are in pocket]

Plates 1-3. Generalized geologic maps-

1. Rolla quadrangle.

2. Paducah quadrangle.

3. St. Louis quadrangle.

Figure 1. Index map

2. Major structural features near the Illinois-Kentucky mining district

\section{TABLE}

TABLE 1. Mineral production in southeast Missouri and Illinois-Kentucky

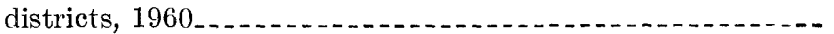





\title{
CONTRIBUTIONS TO ECONOMIC GEOLOGY
}

\section{REGIONAL STRUGTURE OF THE SOUTHEAST MISSOURI AND ILLINOIS-KENTUGKY MINERAL DISTRICTS}

\author{
By A. V. Heyl, M. R. Brock, J. L. Jolly, and C. E. Wells
}

\section{ABSTRACT}

The southeast Missouri and Illinois-Kentucky districts are two of the most important mineral districts in the country in terms of variety of minerals produced, mineral output, and mineral potential. Both districts lie on faulted structural uplifts within the covered shield area of the Central States. Complex fault lineaments intersect in each district and are major structural controls. Two fault zones, the Ste. Generieve and Cottage Grove, form connecting links between districts. The iron deposits of southeast Missouri are in rocks of Precambrian age; but the lead, zinc, barite, copper, cobalt, and pyrite deposits of southeast Missouri, and the fluorite, zinc, barite, lead deposits of IllinoisKentucky, are all in the domed and faulted thin cover of Paleozoic rocks.

\section{INTRODUCTION}

The southeast Missouri and Illinois-Kentucky mineral districts are commercially among the most important mining districts in the United States. These districts lie almost entirely within three quadrangles, the Rolla, St. Louis, and Paducah, of the 1:250,000-map series (fig. 1). A very small part of the Illinois-Kentucky district extends into the Evansville quadrangle (not included in this report), which is east of the Paducah quadrangle. The geology and ore deposits of this small eastern part were described by Weller and Sutton (1951), Weller (1923), and Weller, Sutton, and Crider (1927).

The maps provide a district-wide presentation of mines, prospects, and mineralized areas of the two major mineral districts as well as their relation to the regional framework of the main geologic, topographic, and structural units. The complex structural framework and minor mineralized areas that lie between the two districts are also shown. Fuels, quarry rock, clay, sand, and gravel are not included. 


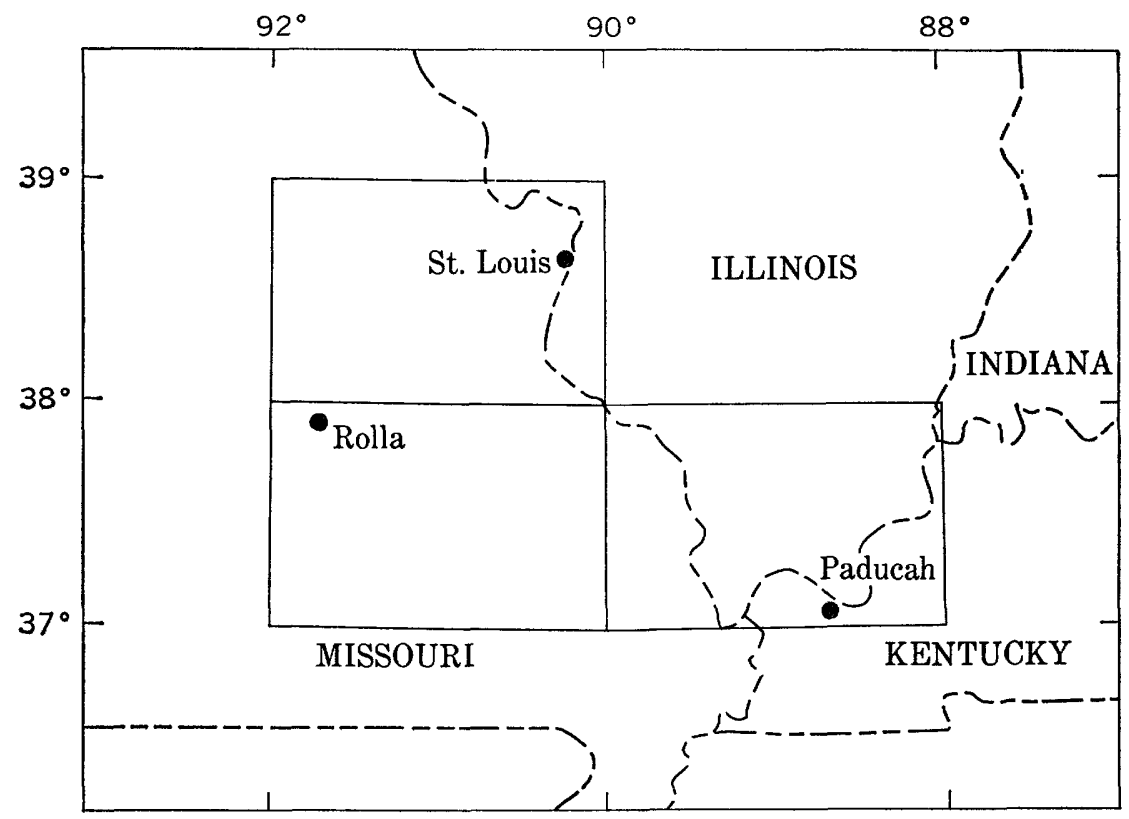

Frauke 1.-Location of the Rolla, Paducah, and St. Louis quadrangles.

The data on geology, structure, and mineral deposits were compiled from many published sources, but especially from the State geological maps of Missouri $(1939,1962)$ and Illinois (Weller and others, 1945), the structure map of Kentucky (Jillson, 1931), and the reports by Weller and Sutton (1951), Weller, Grogan, and Tippie (1952), Ross (1963), Stonehouse and Wilson (1955), Freeman (1945), Kidwell (1947), Winslow (1894), Weller and Ekblaw (1940), Ohle and Brown (1954), Hendricks (1954), James (1949, 1952), Buckley (1909), and Weller and St. Clair (1928).

The authors wish to thank the many individuals, too numerous to acknowledge individually, who provided information for the preparation of the maps. Special thanks are given to R. D. Trace and T. H. Kiilsgaard of the U.S. Geological Survey; J. C. Bradbury of the Illinois State Geological Survey; D. H. Amos, Southern Illinois University ; and E. A. Brecke, consulting geologist.

\section{GENERAL GEOLOGY}

Felsic volcanic rocks, granitic and gabbroic rocks, and a few sedimentary rocks of Precambrian age (pl. 1) are exposed in the northeastern St. Francois Mountains, a part of the Ozark Dome. A nearly complete sequence of sedimentary rocks from Late Cambrian to Late 
Pennsylvanian in age is exposed around the Ozark Dome and eastnortheastward into the southern part of the Illinois basin (pls. 2, 3). To the southeast in Kentucky, southern Illinois, and Missouri (pl. 2) is the upper part of the Mississippi River Embayment, a basin in which the Paleozoic rocks have been progressively downwarped since mid-Cretaceous time, and in which clastic strata of Upper Cretaceous, Paleocene, Eocene, Pliocene, Pleistocene, and Recent age have been deposited.

Summaries of the stratigraphy in southeast Missouri have been given by Ohle and Brown (1954, p. 202-207) ; of the Paleozoic section in southern Illinois, by Weller, Grogan, and Tippie (1952, p. 53-98) and by Baxter, Potter, and Doyle (1963, p. 3-30) ; and of the northernmost Mississippi Embayment, by Ross (1963). The strata above the Precambrian in the Embayment reach a thickness of 12,000-15,000 feet in places.

About 70 small igneous dikes, plugs, and diatremes, mainly of mafic alkalic rocks and intrusive breccia, intrude the Paleozoic rocks in southeast Missouri (Kidwell, 1947) on the northeast flank of the St. Francois Mountains (pl. 1). Another group of similar intrusions is centered in the Illinois-Kentucky district (pl.2) and extends westward along the Cottage Grove fault zone to near West Frankfort in central southern Illinois. Four similar intrusions (Grohskopf, 1955) are south of the mapped area near New Madrid, Mo., about 25 miles south of Cairo, Ill.

\section{STRUCTURE}

The southeast Missouri and Illinois-Kentucky districts lie within a gently warped cratonic region of large gentle domes, basins, and folds. Complex fault systems connect and cross the larger structures (fig. 2). In the Ozark Mountains, in southeastern Missouri, the underlying Precambrian shield has been uplifted to form the broad gentle Ozark Dome, whose structural apex is the St. Francois Mountains (pl. 1). Knobs and peaks of Precambrian granite, granite porphyry, gabbro, and volcanic rocks protrude through the thin cover of partly eroded sedimentary rock to form the low mountains. These knobs represent the exhumed higher parts of a Precambrian surface that was buried by Paleozoic sandstone, limestone, and shale. Similar knobs lie buried beneath the sedimentary cover elsewhere in southeastern Missouri. Some have been located by drilling and by geophysical studies.

Regionally, much of the buried Precambrian surface is broad and undulating; it rises toward the crests of domes and major anticlines such as the Cincinnati arch (fig. 2) in Ohio and Kentucky and the Nashville dome in Tennessee, and descends deeply beneath basins such as the Illinois and Western Kentucky Coal basins and the Mississippi 


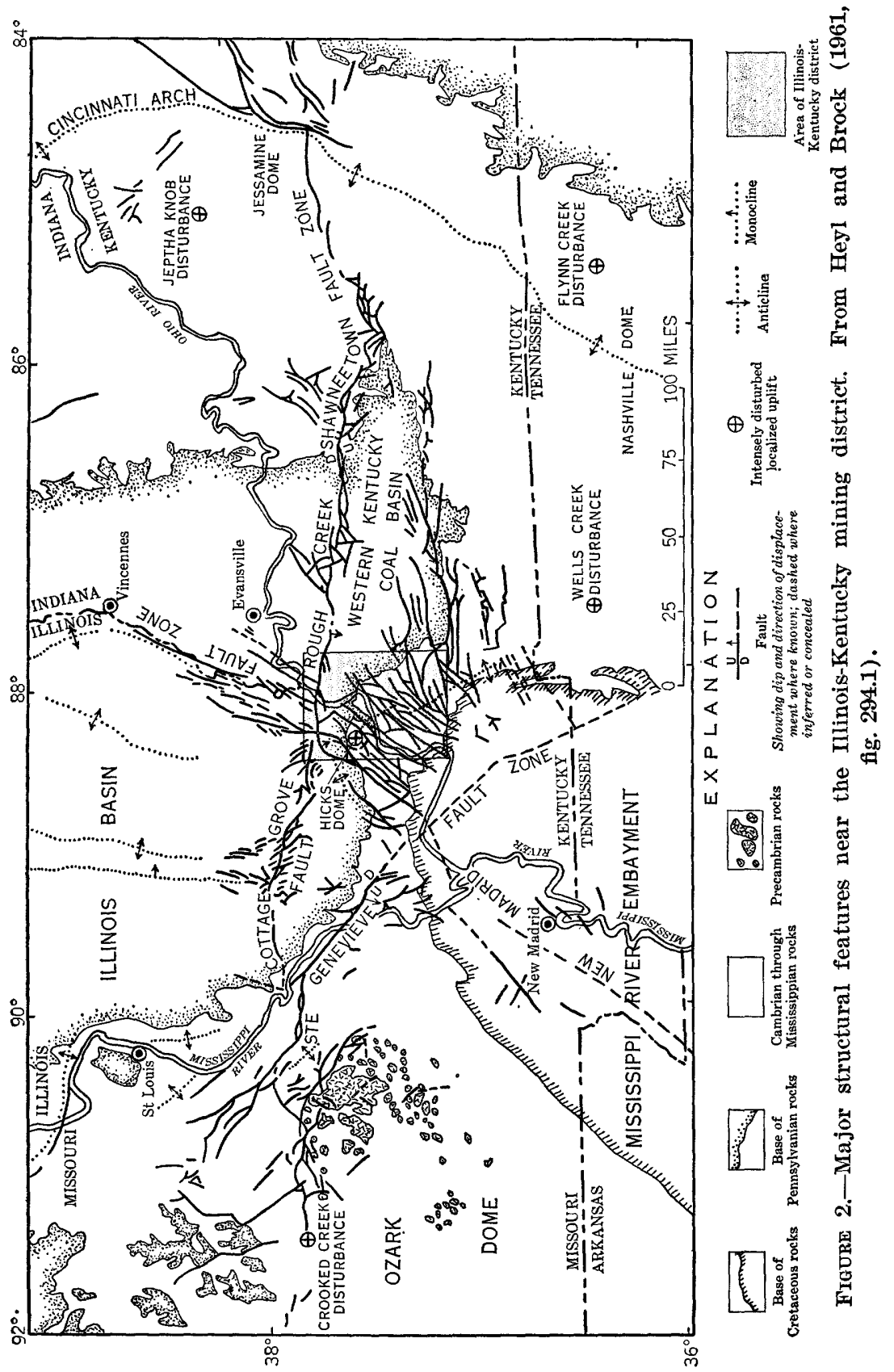


River Embayment. The undulating surface represents warping younger than the Precambrian. Along the major fault zones, the normally gently warped surface is sharply bent and broken. Most larger faults of the area probably are surface expressions of ancient Precambrian lineaments (Clark and Royds, 1940; Heyl and Brock, 1961) along which movement has been renewed at intervals throughout geologic time, up to and including the present.

The basins are of different ages. The Illinois basin started to form by downwarping early in Paleozic time, but its main period of progressive subsidence was during the Mississippian and Pennsylvanian (Weller and Sutton, 1946). Its formation was essentially completed by the end of the Paleozoic Era (Freeman, 1950). The Mississippi River Embayment (fig. 2) did not start to form until the Cretaceous, and it is still being downwarped and filled at the present time.

Both mineral districts are within the most complexly faulted area in the central part of the United States. The southeast Missouri district includes the St. Francois Mountains and vicinity. The iron deposits are in rocks of Precambrian age, but all the other deposits are in the thin cover of faulted Paleozoic rocks that dips gently outward from the St. Francois Mountains. The Illinois-Kentucky district lies within a collapsed, faulted, and partly rotated domal anticline located at or near the intersections of several major faults and fault zones.

Seven major faults and fault zones can be recognized in the region (fig. 2) :

1. The New Madrid fault zone, a broad belt of northeastward-trending faults, extends from near Vincennes, Ind., southwestward through and beyond New Madrid, Mo.

2. The Shawneetown-Rough Creek fault zone is traceable from the collapsed Jessamine Dome (fig. 2) of central Kentucky westward to the New Madrid fault zone near Shawneetown, Ill. (pl. 2), where it curves southwestward around the northwest end of Hicks Dome and joins the northwest side of the New Madrid fault zone.

3. The Ste. Genevieve fault zone, a high-angle thrust fault with associated normal faults (Weller and St. Clair, 1928, p. 264), begins southwest of St. Louis (fig. 2) and extends southeastward into Illinois, where it is named the Rattlesnake Ferry fault (pl.2). A concealed extension of the Ste. Genevieve fault zone in rocks of Paleozoic age has been mapped (Freeman, 1945) in western Kentucky near Paducah.

4. The Cottage Grove fault zone is traceable across southern Illinois to the Mississippi River, where it may end against the Ste. Genevieve system and its branches. To the west, faults of similar 
westward trend-the Big River fault and its western continuations, the Palmer fault zone (pl. 1) - are traceable through the southeast Missouri mineral district to the Crooked Creek disturbance. West of the Crooked Creek structure, in Phelps County (pl. 1), faults have been mapped (Lee, 1913) that lie along the continuation of this westward trend.

5. The Cape Aux Gres fault-and-monocline system trends eastward through Lincoln County, Mo. (pl. 3, northeastern part), into Illinois near Alton.

6. A zone of westward-trending faults along the south boundary of the western Kentucky coal basin (fig. 2) joins the New Madrid fault zone in the southern part of the Illinois-Kentucky mining district between Marion and Kuttawa, Ky. (pl. 2).

7. Vertical and high-angle faults of short length, northwest trend, and small displacement lie within the Illinois-Kentucky district; they are traceable beyond it into the southern part of the Illinois basin (pl. 2, fig. 2). The individual fractures of this system are cut and displaced by short faults of several other systems. Mafic dikes were injected along many of these short faults.

The north end of the Mississippi River Embayment of the Coastal Plain and major parts of the channels of the Mississippi, Ohio, and Wabash Rivers may be partly controlled in this region by longcontinuing movements along the New Madrid and Ste. Genevieve fault sytems. The larger of these two fault systems is the New Madrid fault zone (fig. 2), which has broken the rocks into many narrow fault blocks and wedges that are elongated northeastward. The fault zone (pl.2) extends northeastward from the Mississippi River Embayment, past New Madrid and across the Wabash River, where it has been called the Wabash River fault zone. Woollard (1958, p. 1144) suggested that this fault zone is the southwestern part of a major structural line in the craton. He suggested that it extends northeastward beneath the sedimentary rocks into the St. Lawrence Valley in eastern Canada and the United States and that it is one of the great basement fault zone lineaments of North America. This line is marked by a well-defined belt of earthquake epicenters (Woollard, 1958, figs. 2, 3, 5).

The New Madrid fault zone, the Ste. Genevieve fault zone, faults of the St. Francois Mountains area, and the curved west end of the Rough Creek-Shawneetown fault zone are seismically active today. The New Madrid fault zone, including the wide part of the zone that crosses the Illinois-Kentucky district, is one of the most active seismic areas in the country; more than 25 earthquakes have been recorded along this zone since 1937 . 
The New Madrid earthquake series of 1811-13 included hundreds of quakes, and several of these were among the most violent earthquakes ever recorded anywhere in the world (Fuller, 1912). The very large oval pattern of the epicenters of the earthquake series was elongated northeastward along the New Madrid fault zone across the IllinoisKentucky district, but a branching lobe of the epicenters extended northwestward up the Ste. Genevieve fault system nearly to St. Louis (Fuller, 1912, fig. 1, p. 16). In 1813, during the later period of the earthquake series, the center of greatest disturbance migrated northeastward along the New Madrid fault zone to the vicinity of Saline Mines, Ill. (pl. 2), a fact which suggests that some of the faults that cross the Illinois-Kentucky district may have moved at this time.

The northwestern part of the Ste. Genevieve fault, especially near St. Louis, Mo., marks a second line of much seismic activity in historic times. Scattered earthquake epicenters have occurred all along this fault zone and along the possible southeastern extension of this zone, as far distant as northwestern Tennessee (fig. 2). Several quakes, whose focuses were at a depth of about 40 miles, in the area of the St. Francois Mountains indicate that deep-seated epeirogenic movements are still taking place beneath the apex of the Ozark Dome.

\section{SOUTHEAST MISSOURI DISTRICT}

The southeast Missouri mineral district includes about 4,000 square miles within and around the St. Francois Mountains. The St. Francois Mountains are an elevated cluster of Precambrian rocks in which iron ores were deposited in Precambrian time. By Late Cambrian time the mountains were islands in a shallow sea in which sandstone, limestone, and shale were deposited. Later, the limestone surrounding the mountains was dolonitized in many places. Sandstone and limestone continued to be deposited, so that by the end of the Paleozoic, the summits of the Precambrian islands had been buried to a depth of about 5,000 feet (Ohle and Brown, 1954, p. 211). Subsequent erosion has removed all but thin remnants of the early Paleozoic formations from the central Ozark region.

A network of northwest-, east-, and northeast-trending faults and gentle flexures have modified the St. Francois Mountains and the northern side of the Ozark Dome. In the main lead-producing area of Flat River-Bonne Terre, the original northeastward dip of the sediments has been reversed by southward tilting of the block between the Simms Mountain fault on the southwest and the Big River fault and Ste. Genevieve fault zone on the north. Within the tilted block, several other faults that have vertical components of displacement of 100 feet or less divide and intersect northeast-trending faults that 
have 10 feet or less of vertical displacement. Prominent low-angle slickensides and grooves on most of the smaller faults suggest that the movement has essentially been strike slip. Similar nets of faults, mostly premineralization, are present in the Fredericktown area; and others are closely associated with the lead-barite-zinc veins near Palmer, Valle Mines and Fletcher, and in Franklin County, Mo.

As shown on plates 1 and 3, many of the base-metal and barite deposits lie within faulted and tilted blocks or occur along major fault zones. Examples are the Flat River-Bonne Terre group of mines, those in the Fredericktown area, and the notable clusters of mines near Palmer and Potosi, Mo. Veins of ore in faults are uncommon except in some deposits in Washington County, Mo.

Ohle and Brown (1954, p. 212) stated that:

The controlling influence of three principal types of structure can be demonstrated in Lead Belt [mines near Fredericktown, Bonne Terre and Flat River, Mo.] ore bodies :

(1) Domal or anticlinal structures related to Precambrian knobs and ridges.

(2) Sedimentary arch structures of depositional origin.

(3) Fracture zones.

Ohle $(1959$, p. 779$)$ pointed out that the "knobs" and sedimentary arches commonly are accentuated by algal reefs that grew on top of them as submergence and sedimentation proceeded. The beds on the flanks of the reefs commonly dip $20^{\circ}-40^{\circ}$ and are especially favorable host rocks for lead ore in the Bonneterre Dolomite.

Lead-barite-zinc deposits of the fault-zone type, such as those near Palmer, Mo., furnished most of the lead in the early history of the mineral district and have produced much barite in recent years. The controlling fractures are networks of small faults and joints that have been enlarged in places by solution of the wallrocks. The resultant mineralized openings are discontinuous along the fractures and are very similar to gash-vein lead deposits in Wisconsin (Heyl and others, 1959). The ore bodies are long pods (James, 1952, p. 653) that are restricted to thin stratigraphic zones. More than one zone of ore bodies may be present at the Valle mines. In the Palmer area three levels have been developed (James, 1952, p. 654).

An outlying cluster of fault-controlled lead-zinc vein deposits was found southwest of Rolla, Mo. (pl. 1), in fracture zones related to faults that represent the westward extension of the Palmer fault zone. Other outlying deposits occur east of the main Flat River-Bonne Terre district, along the Ste. Genevieve fault system.

Two of the most unusual structural features in the southeast Missouri district are the Crooked Creek disturbance and the Farmington anticline (pl. 1). The Crooked Creek disturbance is a circular area of 
highly deformed, brecciated rocks about 4 miles in diameter, peripherally bounded by steep faults. The core consists of older rocks that have been uplifted above their original positions. The origin of the structural feature has been a subject of considerable conjecture. The two concepts most commonly advanced are those of subterranean explosion (Kiilsgaard and others, 1963) and of meteoritic impact (Hendricks, 1954; Dietz, 1961). The Crooked Creek disturbance lies at the west end of the well-mapped part of the Palmer fault zone, at its theoretical intersection with the Cuba fault (pls. 1,3). Hayes' (1962) map of the configuration of the Precambrian surface shows that a northwest-trending possible extension of the Black fault passes through the disturbance. The Farmington anticline is a low northwest-trending fold whose southeastern crest is notably faulted and brecciated over a wide area centered near Avon, Mo. (pl. 1). In this disturbed area nearly 70 diatremes and a few dikes of brecciated igneous rock occur. The intrusions consist of both mafic rocks having alkalic affinities and a wide variety of fragmental sedimentary rocks, including fossiliferous Devonian limestone (Kidwell, 1947). The Kattawa arch in the Illinois-Kentucky district (pl. 2) and Hicks Dome, Ill., are structurally similar to the Farmington anticline, and also are cut by numerous small dikes and diatremes of mafic rocks.

\section{ILLINOIS-KENTUCKY DISTRICT}

The Illinois-Kentucky mining district, which has an area of about 1,000 square miles, is in the northern part of a faulted and collapsed north-northwest-trending domal anticline, the structural apex of which is Hicks Dome. The axis of the anticline plunges gently southeastward from the apex into northwestern Kentucky, where it apparently is displaced both northeastward and southwestward by cross faults (pl. 2) and extends south through western Kentucky as the Kuttawa arch. The anticline flattens and weakens south of Princeton, Ky., but extends nearly to the Tennessee State line (fig. 2). The north end of the fold terminates against the arcuate west end of the Shawneetown-Rough Creek fault zone, which in this area is a highangle thrust fault (Weller, 1940, p. 49; see also Stonehouse and Wilson, 1955 , p. 1; Weller and Sutton, 1940, p. 852). It has a vertical displacement of more than 3,000 feet (pl. 2). A branch fault, which probably has a right-lateral component of movement, curves southeastward from the main fault nearly to Saline Mines, Ill.

The main Shawneetown-Rough Creek fault system is a zone of sheared and faulted rock that Clark and Royds (1948) considered to be a wrench-fault system. Outcrops and drill holes (Butts, 1925, figs. 5A, 5B; Freeman, 1950, p. 31-33) suggest that the horizontal 
component of movement was combined with a thrust component along southward-dipping fault planes. Patterns of subsidiary faults and folds (pl. 2) suggest to the writers that the strike-slip component of movement was left lateral. The New Madrid fault zone apparently acted as a shear-relief fracture for the Shawneetown-Rough Creek zone at its western end (pl. 2). Faults in the zone along the south boundary of the western Kentucky basin (fig. 2) have vertical displacements and branches similar to those of the Shawneetown-Rough Creek zone.

That the Cottage Grove fault zone is probably a weaker wrench fault than the Shawneetown-Rough Creek fault zone is shown by its scissors-type vertical displacements (Clark and Royds, 1948, p. 1748). Wrench faulting is suggested also by the arrangement of the abundant subsidiary northwest-trending faults along the Cottage Grove fault zone. The patterns of these subsidiary faults suggest to the writers that the main component of movement was right lateralthat is, that the rocks on the north side of the Cottage Grove fault moved eastward in relation to those on the south side. This direction is the reverse of that proposed by Clark and Royds (1948) for the Shawneetown-Rough Creek fault. The relative positions of the Cottage Creek and Shawneetown-Rough Creek fault systems suggest that the Cottage Creek fault zone may simply be a west-trending branch of the Shawneetown-Rough Creek fault zone.

The faulted anticline within this mining district is dominated by Hicks Dome, a circular structure that has approximately 4,000 feet of vertical uplift and a diameter of about 9 miles (pl. 2). Many northwest-trending tension fractures that formed during the doming are intruded by dikes of mafic rocks. The dome contains a cluster of mineralized explosion breccias in the Devonian rocks in its center and several other breccia-filled diatremes on its flanks. On the flanks of the dome are both radial (J. M. Bradbury, oral commun., 1961) and concentric ring faults and fractures (Weller, Grogan, and Tippie, 1952, pl. 4; Stonehouse and Wilson, 1955). Many of these fractures contain veins that have been mined for fluorite and zinc. The curved changes in the pattern of the northeast-trending faults of the New Madrid system in the central domal area, and the arched segment in the Rock Creek graben suggest that this faulting is younger than the doming (pl.2).

Eleven altered dikes of peridotite that have alkalic affinities lie within the dome. An altered northeast-trending dike just east of the center of the dome is radioactive and enriched in rare earths: barium, beryllium, niobium, gallium, and scandium. In this content, it resembles the fluorite-thorium-rare-earth breccias in the center of the 
dome (Brown, Emery, and Meyer, 1954). The magnetite of the dike reportedly is (P.K. Theobald, written commun. to W. C. Overstreet, 1961) abnormally rich in zinc. Other alkalic peridotite dikes in the dome strike northwestward, parallel to all dikes elsewhere in the area and to the axis of the domal anticline.

Some of the central breccias in Hicks Dome have been drilled (Brown, Emery, and Meyer, 1954) and trenched (Trace, 1960). One radioactive central breccia, that of the Rose mine (pl. 2, loc. 26), has been mined for fluorite. The deepest hole, the Hamp hole, was drilled to a depth of 2,944 feet and was bottomed in intensely brecciated Ordovician rocks. The last 1,600 feet penetrated is composed of strongly mineralized breccia containing a matrix of 2-10 percent fluorite; much barite, quartz, and calcite; and a little pyrite, sphalerite, galena, biotite, brookite, xenotime, rutile, and apatite. Thorium, rare earths, beryllium, zirconium, and niobium are intimately associated with the fluorite and barite in the Hamp hole and increase in amount with these minerals. The mineralogy of the shallow drilling and trenches was studied by Trace (1960), who identified an unusual yttrium-thorium monazite and florencite.

The monazite is relatively unfractionated and is of the deep-seated type that is most likely to have been deposited originally at great depth in the earth's crust (W. C. Overstreet, oral commun., 1960). This conclusion supports the suggestion made by Brown, Emery, and Meyer (1954) that the breccias are mineralized diatremes and that Hicks Dome is a cryptovolcanic structure. The presence of similar elements in both the mineralized breccias and in the dikes and diatremes of the dome (Bradbury, 1962), and also the abundance of fluorite in the breccias, suggest a genetic relationship between the fluorite in this area and that in the rest of the fluorspar-zinc district. Fluorine, gallium, yttrium, niobium, and barium are typical minor elements in igneous rocks of the alkalic series and are characteristic of mineral deposits closely associated with such rocks.

Unlike other domal uplifts of the region, such as the Ozark Dome, the anticline that extends southeast from Hicks Dome was formed during a relatively short period in post-Pennsylvanian time, probably in the Permian, because Pennsylvanian and older rocks are unthinned over the anticline. This domal folding probably was the result of the intrusion of a magma (Weller and others, 1920, p. 55-60) deep within the Precambrian basement at the intersection of several basement fault lineaments. The inferred body of magma probably was large, as shown by the wide extent of the satellitic dikes, sills, and diatremes in the domal area. The first tension fractures to open during uplifting were those parallel to the anticlinal axes (Weller and others, 1920). 
Later, the dome was faulted by the New Madrid system. Cooling and resultant shrinking of the magma then partly collapsed the anticline.

During the final stages of igneous intrusion, possibly during the collapse of the domal anticline, the Hicks Dome breccia was formed in the center of the anticline, probably by gas and steam exploding upward from the buried crest of the intrusion. Sedimentary rocks and earlier intruded biotite-bearing dikes or sills were broken; and yttrium-thorium monazite, brookite, xenotime, and rutile were injected upward into the breccia mass and overlying fractures. Mineralized heated solutions then moved upward into the breccia and deposited fluorite, barite, calcite, pyrite, galena, and sphalerite as a cement in the breccia.

Similar fluorine- and metal-bearing brines, largely connate in origin (Hall and Friedman, 1963), filled the northeast-trending faults and adjacent fractures and deposited the fluorite, zinc, lead, and barite veins and bedded replacements. Hall and Friedman (1963, p. 886) showed that the fluid inclusions in the early ore minerals are nearly saturated sodium-calcium chloride brines somewhat enriched in potassium, particularly those inclusions that formed during the later stages of ore deposition. Hall and Friedman described the chemical composition and relative deuterium concentration of primary fluid inclusions in ore and gangue minerals from the Cave in Rock district, Ill., and the paragenesis of the minerals in the district as follows:

Fluid inclusions in late minerals are less concentrated and have a lower relative deuterium concentration. In the Cave in Rock district the composition of primary fluid inclusions in yellow fluorite, the earliest ore mineral, is similar to that of connate water in the Illinois basin in the same strata as the ore deposits. The change in composition of fluid inclusions in the later quartz and sulfide minerals indicates a water of different origin, possibly magmatic, was introduced. Connate and possible magmatic waters were largely flushed out during the deposition of the gangue minerals in the last stages of mineralization, and the composition of the fluid inclusions in these gangue minerals trends toward that of meteoric water or a dilute mixture of meteoric and magmatic water.

Preliminary lead-isotope analyses by Maryse Delevaux (Hall and Friedman, 1963) show that galena from the Hicks Dome breccia and from the Deardorf and Oxford mines in the Cave in Rock district have very similar isotopic compositions and are both of the radiogenic $\mathbf{J}$ type. These data show a close compositional relationship between the mineralization at Hicks Dome and Cave in Rock, particularly because the galena at Hicks Dome is somewhat enriched in the thorium isotope of lead and the fluorite at Cave in Rock contains small quantities of yttrium. 


\section{MINERAL DEPOSITS}

\section{SOUTHEAST MISSOURI MINERAL DISTRICT}

The southeast Missouri mineral district contains three types of deposits. The crystalline rocks of the St. Francois Mountains contain magnetite and hematite deposits of Precambrian age, which have been mined for many years, as well as a few Precambrian lead-silver-tungsten veins, and barite veins. Precambrian iron deposits have more recently been found at depth beneath the Paleozoic sedimentary rock cover at Pea Ridge (pl. 3, No. 32), Bourbon (pl. 3, No. 26), and Boss (pl. 1, No. 49), Mo. Surrounding all but the south end of the St. Francois Mountains is an arcuate belt of post-Precambrian lead deposits in the Bonneterre Dolomite, known locally as the "Lead Belt," which contains huge disseminated lead deposits associated in places with copper, cobalt, nickel, and a little silver and zinc.

North and northwest of the St. Francois Mountains, extending far northward through Washington County, Mo. (pl. 3), are lead-baritezinc veins, irregular replacements, and runs that have been mined in recent years mostly for barite from the weathered residuum. Prior to 1900 these deposits were major sources of lead, and then zinc. To a considerable extent the deposits overlap the northern part of both the Lead Belt and the still deeper iron deposits. A few filled sinks of iron sulfides in limestone also occur within this northern area (pl. 3), but more exist farther west near Rolla, Mo. (pl. 1).

This large mineralized region was defined and described years ago by Winslow (1894) as the Southeast Missouri district. The limits he designated and the present ones are very similar, confirmed by the fact that large new lead and iron deposits have been found in recent years far northwest and southwest of those which were productive from $1930-55$.

\section{ILLINOIS-KENTUCKY MINERAL DISTRICT}

The fluorspar, zinc, lead, barite, and rare-earth deposits of the Illinois-Kentucky mineral district can be divided into four types: vein deposits, which are the most abundant and productive; beddedreplacement deposits, which are the largest and have been the most productive in recent years; residual or gravel fluorspar and barite deposits; and the explosion breccia deposits that contain fluorite, barite, and rare-earth minerals in the central part of Hicks Dome. The principal fluorspar-zinc-lead bodies in the important Cave in Rock district, Ill. (pl. 2), are bedded-replacement deposits, whereas most of those mined in the Rosiclare area, Ill., and in Kentucky are vein deposits. A few bedded-replacement deposits are associated with 
some of the veins in Kentucky, and mixed vein and replacement deposits are known to exist west of Hicks Dome in Illinois. The residual or gravel-fluorspar and barite deposits originated from the weathering of the veins.

Most of the large vein deposits are in northeastward-trending faults and in eastward-trending faults south and west of Marion, Ky.; but in places, smaller commercial deposits occur in cross or northwesttrending faults and other fractures. Some of these deposits, such as those at the Hutson mine (pl. 2, loc. 16) and the Old Jim mine (pl. 2, loc. 11), consist of sphalerite with only traces of fluorite; others are mainly fluorite veins. Some of the vein deposits are fissure fillings with very little replacement of the wallrock, whereas others have replaced relatively large amounts of shattered calcite or limestone. In some veins, minerals cement breccia fragments. The bedded-replacement deposits are mantolike bodies of fluorite, sphalerite, and other minerals that filled and replaced favorable limestone beds outward on one or both sides of mineralized faults or fractures. Downdip, some of these deposits terminate in breccia pipes (Brecke, 1962).

The principal ore minerals are calcite, fluorite, sphalerite, barite, and galena. Quartz, marcasite, pyrite, ankerite or ferroan dolomite, witherite, celestite, strontianite, and chalcopyrite occur as gangue minerals. Silicified explosion breccias in diatremes and breccia dikes in the Hicks Dome cryptovolcano structure contain green and white fluorite, barite, quartz, galena, monazite, florencite, xenotime, rutile, and many other minerals. Some of these bodies have been prospected for thorium and rare earths (Trace, 1960), and at least one, the Rose mine (pl. 2, loc. 26), has produced fluorite commercially.

\section{RESOURCES}

Southeast Missouri is one of the largest and most productive lead districts in the world. It is also a major barite district and a source of byproduct zinc and silver (table 1). Several large magnetite and hematite deposits are in the district, two of which were mined productively in 1965. Smaller quantities of copper, cobalt, nickel, and pyrite have been produced. The Illinois-Kentucky district is the most important commercial fluorspar district in the United Statesa major source of germanium-, cadmium-, and gallium-rich zinc ore, and a source of lead and barite. Low-grade deposits of thorium, niobium, beryllium, and rare-earth elements have been prospected at the center of Hicks Dome, Ill. (Trace, 1960, p. B63-B64; Bradbury, 1962). Limestone in the area is a major source of crushed stone near St. Louis and Ste. Genevieve, Mo.; Anna and Cave in Rock, Ml.; Lake City, Fredonia, and Mattoon, Ky. Commercially important coal, oil, and gas fields occur in southern Illinois. 
TABLE 1.-Mineral production in southeast Missouri and Illinois-Kentucky districts, 1960

[Data compiled from U.S. Bur. Mines, Minerals Yearbook for 1960]

\begin{tabular}{|c|c|c|c|c|}
\hline \multirow[b]{2}{*}{ Mineral } & \multicolumn{2}{|c|}{ Southeast Missouri } & \multicolumn{2}{|c|}{ Illinois-Kentucky } \\
\hline & Quantity 1 & Value & $\begin{array}{c}\text { Quantity } \\
\text { (short tons) }\end{array}$ & Value \\
\hline $\begin{array}{l}\text { Iron ore } \\
\text { Barite } \\
\text { Copper (recoverable con } \\
\text { tent of metal in ore) } \\
\text { Lead. } \\
\text { Zinc. } \\
\text { Fluorspar } \\
\text { Silver } \\
\text { Cobalt } \\
\text { Nickel } \\
\text { Cadmium, gallium, ger } \\
\text { manium }\end{array}$ & $\begin{array}{r}1,087 \\
111,948 \\
2,821 \\
\text { None } \\
315,594 \\
(5) \\
(5) \\
\text { None }\end{array}$ & $\begin{array}{r}\$ 3,760,000 \\
2,588,000 \\
\\
698,000 \\
26,196,000 \\
728,000 \\
\text { None } \\
314,000 \\
(5) \\
(5) \\
\text { None }\end{array}$ & $\begin{array}{l}\text { None } \\
(2) \\
\text { None } \\
2,313 \\
10,994 \\
160,384 \\
\text { None } \\
\text { None } \\
\text { None } \\
(6)\end{array}$ & $\begin{array}{r}\text { None } \\
\$ 541,000 \\
2,604,000 \\
8,109,000 \\
4 \text { None } \\
\text { None } \\
\text { None } \\
\left.{ }^{6}\right)\end{array}$ \\
\hline
\end{tabular}

1 Quantities, southeast Missouri: iron ore, long tons; barite, copper, lead, and zinc, short tons; silver, troy ounces.

2 In 1961 Kentucky produced 3,304 short tons of barite valued at $\$ 30,000$. The 1960 production figures are not available.

3 In 1959 when the demand for desilverized lead was much greater, southeast Missouri produced 339,760 ounces valued at $\$ 308,000$. Silver is recovered from both zinc and lead concentrates.

In 1956, the last year of silver production, Illinois produced 1,580 troy ounces valued at $\$ 1,430 ;$ and in 1959 Kentucky produced 75 troy ounces valued at $\$ 68$. Silver is recovered from galena.

5 Cobalt and nickel were produced in 1960 from Fredericktown, Mo., by the National Lead Co. Southeast Missouri has been a major source of cobalt and nickel for many years, but production figures are not available.

6 Cadmium, gallium, and germanium were produced in Illinois-Kentucky as byproducts of zinc production.

Both the Illinois-Kentucky and southeast Missouri mineral districts have notably large reserves of ore. The Illinois-Kentucky mineral district was estimated in 1956 to have 54 percent of the higher grade fluorspar reserves in the United States (R. E. Van Alstine, written commun., 1956). These estimated reserves total 12,100,000 tons of measured, indicated, and inferred ore which contains at least 35 percent $\mathrm{CaF}_{2}$ or sufficient zinc and lead to give it an equivalent value. About half of the ore contains an average of 3 percent zinc, and approximately one million tons contains about 1 percent lead. The zinc ore contains notable cadmium, germanium, and gallium; and some of the lead ore contains silver. All the higher grade fluorspar reserves are probably amenable to beneficiation into acid-grade and (or) metallurgical-grade concentrates. In addition, sizeable areas having economic potential that have not been adequately explored remain in the district.

The southeast Missouri mineral district has very large reserves of lead, iron, and barite ore. These have been found in recent years by several companies through extensive exploration programs. Widespread geophysical programs by the U.S. Geological Survey and the Missouri Division of Geological Survey and Water Resources have 
aided in this exploration. Some of the lead reserves are east and northeast of the St. Francois Mountains, but most of them are in new areas west and northwest of the mountains (pls. 1, 3). New mines in the Indian Creek and Viburnum areas are now (1965) in production; others are being planned or developed in the Bee Fork, Higdon, and in the Logan Creek-Blair Creek areas. Some of the southeast Missouri lead ore contains notable quantities of silver- and cadmium-bearing sphalerite which can be produced as a byproduct, and some of the lead ore is associated with copper, nickel, and cobalt minerals that are potential byproducts. Major iron deposits have been found in recent years at Pea Ridge, Ironton, Bourbon, and Boss in the buried Precambrian basement. The Pea Ridge deposit is now (1965) a major iron producer. Copper occurs with the iron ore at Boss.

\section{SELECTED REFERENCES}

Bain, H. F., 1905, Fluorspar deposits of southern Illinois: U.S. Geol. Survey Bull. 255, $75 \mathrm{p}$.

Ball, S. H., and Singewald, J. T., Jr., 1930, An alnoite pipe, its contact phenomena, and ore deposition near Avon, Missouri : Jour. Geology, v. 38, no. 5, p. 456-459.

Bastin, E. S., 1931, The fluorspar deposits of Hardin and Pope Counties, Illinois : Illinois Geol. Survey Bull. 58, 116 p.

Bastin, E. S., and others, 1939, Contributions to a knowledge of the lead and zinc deposits of the Mississippi Valley region: Geol. Soc. America Spec. Paper 24, $156 \mathrm{p}$.

Baxter, J. W., Potter, P. E., Doyle, F. L., 1963, Areal geology of the Illinois fluorspar district, Pt. I, Saline Mines, Cave in Rock, Dekoven, and Repton quadrangles : Illinois Geol. Survey Circ. 342,43 p.

Bradbury, J. C., 1962, Trace elements, rare earths, and chemical composition of southern Illinois igneous rocks : Illinois Geol. Survey Circ. 330, 12 p.

Brecke, E. A., 1962, Ore genesis of the Cave in Rock fluorspar district, Hardin County, Illinois : Econ. Geology, v. 57, no. 4, p. 499-535.

Bridge, Josiah, 1930, The geology of the Eminence and Cardareva quadrangles: Missouri Bur. Geology and Mines, 2d ser., v. 24, 228 p.

Brock, M. R., and Heyl, A. V., 1961, Post-Cambrian igneous rocks of the central craton, western Appalachian Mountains and Gulf Coastal Plain of the United States, in Short papers in the geologic and hydrologic sciences: U.S. Geol. Survey Prof. Paper 424-D, p. D33-D35.

Brown, J. S., 1958, Southeast Missouri Lead Belt, in Geol. Soc. America Guidebook, Field Trip 1, p. 1-7.

Brown, J. S., Emery, J. A., and Meyer, P. A., Jr., 1954, Explosion pipe in test well on Hicks Dome, Hardin County, nlinois: Econ. Geology, v. 49, no. 8, p. 891-902.

Buckley, E. R., 1909, Geology of the disseminated lead deposits of St. Francois and Washington Counties, Missouri: Missouri Bur. Geology and Mines 9, pt. 1, 259 p.

Butts, Charles, 1925, Geology and mineral resources of the Equality-Shawneetown area : Illinois Geol. Survey Bull. 47, 76 p. 
Cady, G. H., and others, 1951, Subsurface geology and coal resources of the Pennsylvanian system in certain counties of the Illinois Basin [Clay, Edwards, Gallatin, Hamilton, and Richmond Counties] : Illinois Geol. Survey Rept. Inv. 148, 123 p., app., 151 p.

Christiansen, C. R., and others, 1959, Mining and milling methods and costs at the Indian Creek mine, St. Joseph Lead Co., Washington County, Missouri : U.S. Bur. Mines Inf. Circ. 7875,47 p.

Clark, S. K., and Royds, J. S., 1948, Structural trends and fault systems in Eastern Interior Basin: Am. Assoc. Petroleum Geologists Bull., v. 32, p. 17281749 .

Clegg, K. E., 1955, Metamorphism of coal by peridotite dikes in southern Illinois: Illinois Geol. Survey Rept. Inv. 178, 18 p.

Clegg, K. E., and Bradbury, J. C., 1956, Igneous intrusive rocks in Illinois and their economic significance: Illinois Geol. Survey Rept. Inv. 197, $19 \mathrm{p}$.

Crane, G. W., 1912, The iron ores of Missouri : Missouri Bur. Geology and Mines, ser. 2, v. 10, 434 p.

Currier, L. W., 1923, Fluorspar deposits of Kentucky ; a description and interpretation of the geologic oceurrence and industrial importance of Kentucky fluorspar: Kentucky Geol. Survey, ser. 6, v. 13, 198 p.

Currier, L. W., and Wagner, O. E., 1944, Geology of the Cave in Rock district, pt. 1 of Geological and geophysical survey of fluorspar areas in Hardin County, Illinois: U.S. Geol. Survey Bull. 942, p. 1-72.

Dake, C. L., 1930, Geology of Potosi and Edgehill quadrangles: Missouri Bur. Geology and Mines, $2 d$ ser., v. 23, 233 p.

Desborough, G. A., 1961, Geology of the Pomona quadrangle, Illinois: Illinois Geol. Survey Circ. 320, 16 p.

Dietz, R. S., 1961, Astroblemes : Sci. Am., v. 205, no. 2, p. 50-71.

Emmons, W. H., 1929, The origin of the deposits of sulfide ores of the Mississippi Valley : Econ. Geology, v. 24, no. 3, p. 221-271.

English, R. MI., and Grogan, R. M., 1948, Omaha pool and mica-peridotite intrusives, Gallatin County, Illinois, in Howell, J. V., ed., Structure of typical American oil fields, v. 3: Tulsa, Okla., Am. Assoc. Petroleum Geologists, p. 189-212; also issued as Illinois Geol. Survey Rept. Inv. 130.

Farrar, Willard, and McManamy, Lyle, 1937, The geology of Stoddard County, Missouri : Missouri Geol. Survey, 59th Biemn. Rept. 1935-36, app. 6, 92 p.

Fenneman, N. M., 1911, Geology and mineral resources of the St. Louis quadrangle, Missouri-Illinois : U.S. Geol. Survey Bull. 438, 73 p.

Flint, R. F., 1926, Thrust faults in southeastern Missouri: Am. Jour. Sci., 5th ser., v. 12, p. $37-40$.

Freeman, L. B., 1945, Paleozoic structure and stratigraphy, in Geology and mineral resources of the Jackson Purchase region, Kentucky: Kentucky Dept. Mines and Minerals, Geol. Div. Bull., ser. 8, no. 8, p. 12-43.

1950, Paleozoic structure and stratigraphy [of the Jackson Purchase region, Kentucky] : Kentucky Geol. Survey Bull., ser. 9, no. 4, p. 12-36.

Fuller, M. L., 1912, The New Madrid earthquake: U.S. Geol. Survey Bull. 494, $119 \mathrm{p}$.

Grawe, O. R., 1945, Pyrite deposits of Missouri: Missouri Geol. Survey and Water Resources, 2d ser., v. 30, $482 \mathrm{p}$.

Grohskopf, J. G., 1955, Subsurface geology of the Mississippi embayment of southeast Missouri: Missouri Geol. Survey and Water Resources [Rept.], 2 d ser., $\nabla .37,133$ p. 
Grohskopf, J. G., and Hundhausen, Mary, 1987, Occurrence of dickite and fluorite : Missouri Geol. Survey and Water Resources 59th Bienn. Rept., 1935-36, app. 3, $13 \mathrm{p}$.

Hall, W. E., and Friedman, Irving, 1963, Composition of fluid inclusions, CaveIn-Rock fluorite district, Illinois and Upper Mississippi Valley zinc-lead district : Econ. Geology, v. 58, no. 6, p. 886-911.

Hardin, G. C., Jr., 1955, Babb fault system, Crittenden and Livingston Counties, in pt. 1 of Fluorspar deposits in western Kentucky : U.S. Geol. Survey Bull. 1012-B, p. 7-37.

Hardin, G. C., Jr., and Trace, R. D., 1959, Geology and fluorspar deposits, Big Four fault system, Crittenden County, Kentucky: U.S. Geol. Survey Bull. 1042-S, p. 699-724.

Hayes, W. C., 1962, Map showing configuration of the Precambrian surface: Missouri Geol. Survey and Water Resources.

Hendricks, H. E., 1954, The geology of the Steelville quadrangle, Missouri : Missouri Geol. Survey and Water Resources [Rept.], 2d ser., v. 36, $88 \mathrm{p}$.

Heyl, A. V., Jr., Agnew, A. F., Lyons, E. J., and Behre, C. H., Jr., 1959, The geology of the upper Mississippi Valley zinc-lead district: U.S. Geol. Survey Prof, Paper 309, 310 p.

Heyl, A. V., Jr., and Brock, M. R., 1961, Structural framework of the IllinoisKentucky mining district and its relation to mineral deposits, in Short papers in the geologic and hydrologic sciences: U.S. Geol, Survey Prof. Paper 424-D, p. D3-D6.

James, J. A., 1949, Geologic relationships of the ore deposits in the Fredericktown area, Missouri: Missouri Geol. Survey and Water Resources Rept. Inv. $8,25 \mathrm{p}$.

1952, Structural environments of the lead deposits in the southeastern Missouri mining district: Econ. Geology, v. 47, no. 6, p. 650-660.

Jillson, W. R., 1928, The geology and mineral resources of Kentucky; a brief description of the physiography, stratigraphy, . . . : Kentucky Geol. Survey, ser. 6, v. 17, p. 409, [1929].

1931, Structural geologic map of Kentucky: Kentucky Geol. Survey, Ser. 6.

Kidwell, A. L., 1947, Post-Devonian igneous activity in southeastern Missouri : Missouri Geol. Survey and Water Resources Rept. Inv. 4, 83 p.

1951, Mesozoic igneous activity in the northern Gulf Coastal Plain, in Gulf-Coast Assoc. Geol. Socs., 1st Ann. Meeting, p. 182-199.

Kiilsgaard, T. H., and others, 1963, The Crooked Creek disturbance, southeast Missouri: U.S. Geol. Survey Prof. Paper 450-E, p. E14-E19.

Klepser, H. J., 1954, Senator-Schwenck area, Tabb fault system, Caldwell County, in pt. 3 of Fluorspar deposits in western Kentucky: U.S. Geol. Survey Bull. 1012-F, p. 115-127.

Krey, Frank, 1924, Structural reconnaissance of the Mississippi Valley area from Old Monroe, Missouri, to Nauvoo, Illinois: Illinois Geol. Survey Bull. 45, 86 p. ; Missouri Bur. Geology and Mines, $2 d$ ser., v. 18, 86 p.

Lamar, J. E., 1925, Geology and mineral resources of the Carbondale quadrangle: Illinois Geol. Survey Bull. 48, $172 \mathrm{p}$.

Lamar, J. E., and Sutton, A. H., 1930, Cretaceous and Tertiary sediments of Kentucky, Illinois, and Missouri: Am. Assoc. Petroleum Geologists Bull., v. 14, no. 7, p. 845-866.

Lee, Wallace, 1914, The geology of the Rolla quadrangle: Missouri Bur. Geology and Mines, $2 \mathrm{~d}$ ser., v. 12, $111 \mathrm{p}$. 
MeGinnis, L. D., 1963, Earthquakes and crustal movement as related to water load in the Mississippi Valley region: Illinois Geol. Survey Circ. 344, 20 p.

Mining Congress Journal, 1962, Magnetic highs in southeast Missouri being drilled : Mining Cong. Jour., v. 58, no. 5, p. 45.

Mining World, 1962a, From Oates to Eminence, another lead belt?: Mining World, จ. 24, no. 10, p. 29.

1962b, The new lead belt: Mining World, v. 24, no. 12, p. 30.

Missouri Division of Geological Survey and Water Resources, 1939, Geological map of Missouri.

1962, Geological map of Missouri.

Moneymaker, B. C., 1960, Earthquakes felt in Kentucky from 1776 through 1959 [abs.] : Geol. Soc. America Bull., v. 71, no. 12, pt. 2, p. 2022.

Ohle, E. L., Jr., 1959, Some considerations in determining the origin of ore deposits of the Mississippi Valley type : Econ. Geology, v. 54, no. 5, p. 769-789.

Ohle, E. L., Jr., and Brown, J. S., 1954, Geologic problems in the Southeast Missouri lead district: Geol. Soc. America Bull., v. 65, no. 3, p. 201-221; supp., no. 9 , p. $935-936$.

Pryor, W. A., and Ross, C. A., 1962, Geology of the Illinois part of the Cairo, La Center, and Thebes quadrangles: Illinois Geol. Survey Circ. 332, 39 p.

Rogers, W. B., 1963, Geology of the Eddyville quadrangle, Kentucky : U.S. Geol. Survey Geol. Quad. Map GQ-225.

Ross, C. A., 1963, Structural framework of southernmost Illinois: Illinois Geol. Survey Circ. 351, 27 p.

Rubey, W. W., 1952, Geology and mineral resources of the Hardin and Brussels quadrangles (in Illinois) : U.S. Geol. Survey Prof. Paper 218, 179 p.

Rust, G. W., 1937, Preliminary notes on explosive volcanism in southeastern Missouri : Jour. Geology, v. 45, no. 1, p. 48-75.

Snyder, F. G., and Emery, J. A., 1956, Geology in development and mining, southeast Missouri Lead Belt: Mining Eng., v. 8, no. 12, p. 1216-1224.

Snyder, F. G., and Gerdemann, P. E., 1963, Explosive igneous activity along an Illinois-Missouri-Kansas axis in Paleozoic time [abs.]: Geol. Soc. America Spec. Paper 76, p. 154.

Spurr, J. E., 1926a, The Kentucky-Illinois ore magmatic district: Eng. and Min. Jour., v. 122, no. 18, p. 695-699; v. 122, no. 19, p. 731-738.

1926b, The southeast Missouri ore magmatic district: Eng. and Min. Jour., v. 122 , no. 25 , p. 968-975.

Stearns, R. G., and Marcher, M. V., 1962, Late Cretaceous and subsequent structural development of the northern Mississippi Embayment area: Geol. Soc. America Bull., v. 73, p. 1387-1394.

Stonehouse, H. B., and Wilson, G. M., 1955, Faults and other structures in southern Illinois-a compilation: Illinois Geol. Survey Circ. 195, 4 p.

Tarr, W. A., 1918, The barite deposits of Missouri and the geology of the barite district: Missouri Univ. Studies, v. 3, no. 1, 111 p.

- 1936, Origin of the southeastern Missouri lead deposits, Part 1: Econ. Geology, r. 31, no. 7, p. 712-754; pt. 2, no. 8, p. 832-866.

Tennison, Arthur, 1962, Mineral Industry News: Missouri Geol. Survey and Water Resources.

Thurston, W. R., and Hardin, G. C., Jr., 1954, Moore Hill fault system, Crittenden and Livingston Counties, in pt. 3 of fluorspar deposits in western Kentucky: U.S. Geol. Survey Bull. 1012-E, p. 81-113.

Trace, R. D., 1954a, Central part of the Commodore fault system, Crittenden County, in pt. 2 of Fluorspar deposits in western Kentucky : U.S. Geol. Survey Bull. 1012-C, p. 39-57. 
Trace, R. D., 1954b, Mineral Ridge area, Livingston and Crittenden Counties, in pt. 2 of Fluorspar deposits in western Kentucky: U.S. Geol. Survey Bull. 1012-D, p. 59-79.

1960, Significance of unusual mineral occurrence at Hicks Dome, Hardin County, Illinois, in Short papers in the geological sciences: U.S. Geol. Survey Prof. Paper 400-B, p. B63-B64.

1962, Geology of the Salem quadrangle, Kentucky : U.S. Geol, Survey Map GQ-206.

Ulrich, E. O., and Smith, W. S. T., 1905, The lead, zinc, and fluorspar deposits of western Kentucky: U.S. Geol. Survey Prof. Paper 36, $218 \mathrm{p}$.

United States Bureau of Mines, 1960, Minerals Yearbook: Annual volume for 1960.

Wagner, R. E., 1947, "Lead-Belt" geology [St. Joseph lead enterprize, Missouri] : Mining and Metallurgy, v. 28, no. 488, p. 366-368.

Weller, J. M., 1940, Geology and oil possibilities of extreme southern Illinois, Union, Johnson, Pope, Hardin, Alexander, Pulaski, and Massac Counties: Illinois Geol. Survey Rept. Inv. 71, 71 p.

Weller, J. M., and Ekblaw, G. E., 1940, Preliminary geologic map of parts of the Alto Pass, Jonesboro, and Thebes quadrangles: Illinois Geol. Survey Rept. Inv. 70, $26 \mathrm{p}$.

Weller, J. M., Grogan, R. M., and Tippie, F. E., 1952, Geology of the fluorspar deposits of Illinois : Illinois Geol. Survey Bull. 76, $147 \mathrm{p}$.

Weller, J. M., and Sutton, A. H., 1940, Mississippian border of Eastern Interior basin: Am. Assoc. Petroleum Geologists Bull., v. 24, no. 5, p. 765-858; correction, no 6, p. 1133, [1940].

Weller, J. M., and others, 1945, Geologic map of Illinois : Illinois Geol. Survey.

Weller, Stuart, 1923, Geology of the Princeton quadrangle: Kentucky Geol. Survey, ser. 6, v. 10, p. 1-105.

1927, Geology of the Cave in Rock quadrangle: Kentucky Geol. Survey, ser. 6 , v. 26, p. 1-128.

Weller, Stuart, Butts, Charles, Currier, L. W., and Salisbury, R. D., 1920, The geology of Hardin County and the adjoining part of Pope County : Illinois Geol. Survey Bull. 41, 416 p.

Weller, Stuart, and Krey, F. F., 1939, Preliminary geologic map of the Mississippian formations in the Dongola, Vienna, and Brownfield quadrangles; Explanation and stratigraphic summary, by James Marvin Weller: Illinois Geol. Survey Rept. Inv. 60, $11 \mathrm{p}$.

Weller, Stuart, and St. Clair, Stuart, 1928, Geology of Ste. Genevieve County, Missouri : Missouri Bur. Geology and Mines, 2d ser., v. 22, 352 p.

Weller, Stuart, and Sutton, A. H., 1951, Geologic map of the western Kentucky fluorspar district: U.S. Geol. Survey Mineral Inv. Field Studies Map MF-2.

Weller, Stuart, Sutton, A. H., and Crider, A. F., 1927, Map of the areal and structural geology (fault pattern) of Caldwell County, Kentucky: Kentucky Geol. Survey, Ser. 6.

Williams, J. S., and Duncan, Helen, 1955, Introduction to Pt. 1 of Fluorspar deposits in western Kentucky : U.S. Geol. Survey Bull. 1012-A, p. 1-6.

Winslow, Arthur, 1894, Lead and zinc deposits: Missouri Geol. Survey, v. 6-7, $763 \mathrm{p}$.

Woollard, G. P., 1958, Areas of tectonic activity in the United States as indicated by earthquake epicenters: Am. Geophys. Union Trans., v. 39, no. 6, p. 11351150 . 